\title{
Pelapisan benih melon (Cucumis melo L.) dengan ekstrak kulit jeruk untuk mempertahankan mutu fisiologis benih selama penyimpanan
}

\author{
(Melon (Cucumis melo L.) seed coating with orange peel extract to maintain physiological \\ quality of seed during storage)
}

\author{
N. Anisa, F. Kusmiyati dan Karno \\ Agroecotechnology, Faculty of Animal and Agricultural Sciences, Diponegoro University \\ Tembalang Campus, Semarang 50275 - Indonesia \\ Corresponding E-mail: anisanurul265@gmail.com
}

\begin{abstract}
The objective of this research was to study the effectiveness of orange peel extract as seed coating to mantain physiological quality of melon seed during 12 weeks storage. This research was conducted in Laboratory of Plant Physiology and Breeding, Faculty of Animal and Agricultural Sciences, Diponegoro University, from December 2016 to April 2017. The research was assigned in completely randomized factorial design with the first factor was the storage periode $(0,4,8$ and 12 weeks) and second factor was the seed coating (control, CMC 1,5\%, orange peel extract $(0,5 \%, 1,0 \%, 1,5 \%, 2,0 \%)$ ). Interaction of storage period and seed coating showed significant affect to seed moisture content, seed germination and dry weight of normal seedling. Seed coating with orange peel extract $1,5 \%$ was able to keep moisture content for 4 weeks, seed germination for 12 weeks and dry weight of normal seedling for 8 weeks.
\end{abstract}

Keywords: melon, orange peel extract, physiological quality, seed storage

\begin{abstract}
ABSTRAK
Penelitian ini bertujuan untuk mengkaji keefektifan ekstrak kulit jeruk sebagai pelapis benih dalam mempertahankan mutu fisiologis benih melon selama penyimpanan 12 minggu. Penelitian dilaksanakan pada Desember 2016 hingga April 2017 di Laboratorium Fisiologi dan Pemuliaan Tanaman, Fakultas Peternakan dan Pertanian, Universitas Diponegoro. Penelitian disusun dengan rancangan acak lengkap faktorial dengan faktor pertama adalah periode simpan $0,4,8$ dan 12 minggu dan faktor kedua adalah kontrol, pelapisan CMC 1,5\%, ekstrak kulit jeruk 0,5\%, 1,0\%, 1,5\% dan 2,0\%. Hasil penelitian menunjukkan adanya interaksi antara periode simpan dan pelapisan benih terhadap kadar air benih, daya berkecambah dan berat kering kecambah normal. Bahan pelapis ekstrak kulit jeruk $1,5 \%$ dapat mempertahankan kadar air benih hingga minggu ke-4, daya berkecambah hingga minggu ke-12 serta berat kering kecambah normal hingga minggu ke-8.

Kata kunci: melon, ekstrak kulit jeruk, mutu fisiologis, penyimpanan benih
\end{abstract}

\section{PENDAHULUAN}

Melon (Cucumis melo L.) merupakan salah satu tanaman semusim yang banyak dibudidayakan oleh masyarakat karena memiliki kandungan gizi dan nilai jual tinggi. Berdasarkan data dari Badan Pusat Statistik (2016) bahwa produksi melon di Indonesia dari tahun 2012 sampai 2015 berturut-turut adalah 125.474 ton, 125.207 ton, 150.356 ton dan 137.887 ton, sedangkan konsumsi melon per kapita di Indonesia dari tahun 2012 sampai 2015 adalah $0,21 \mathrm{~kg}, 0,42 \mathrm{~kg}, 0,42 \mathrm{~kg}$ dan $0,42 \mathrm{~kg}$. Konsumsi melon tersebut relatif rendah dan diperkirakan akan meningkat seiring dengan peningkatan jumlah penduduk setiap tahunnya, sehingga diperlukan peningkatan produksi melon, salah satunya dengan penggunaan benih melon yang bermutu tinggi.

Salah satu masalah dalam produksi benih 
melon adalah mutu benih melon yang digunakan masih rendah. Mutu benih terdiri atas mutu fisiologis, mutu fisik dan mutu genetis (Pitojo, 2005). Umumnya benih melon disimpan terlebih dahulu sebelum ditanam pada musim tanam berikutnya, sehingga benih melon mengalami kemunduran benih. Kemunduran benih melon dapat mempengaruhi mutu fisiologis benih seperti kadar air benih tinggi (Sari et al., 2013) dan viabilitas benih menurun (Halimursyadah, 2012).

Salah satu alternatif untuk mengatasi masalah tersebut adalah dengan memberikan perlakuan pelapisan benih, yaitu pembungkusan benih dengan zat tertentu yang bertujuan untuk melindungi benih dari pengaruh kondisi lingkungan, mempertahankan kadar air benih dan memperpanjang daya simpan benih. Bahan pelapis benih yang digunakan harus dapat mempertahankan kadar air benih selama penyimpanan, dapat meminimalisir laju respirasi benih, tidak bersifat toksik terhadap benih, bersifat mudah pecah dan larut air, porous, tidak mudah mencair, bersifat higroskopis, tidak bereaksi dengan pestisida, mudah diperoleh dan relatif murah (Kuswanto, 2003).

Jenis bahan pelapis benih yang dapat digunakan adalah arabic gum, carboxyl methyl cellulose (CMC), chitosan dan pektin. CMC merupakan karbohidrat stabil yang dapat melapisi benih secara kompak dan merata (Agustiansyah et al., 2016). Pektin dapat menahan degradasi terhadap panas, kimia, biologis, dapat mengikat air, membentuk gel (Dhaneswari et al., 2015) dan dapat larut dalam air (Sulihono et al., 2012). Pektin dapat diperoleh dari ekstrak buah apel, kulit jeruk, gula bit dan bunga matahari (Georgiev et al., 2012). Penggunaan kulit jeruk sebagai penghasil pektin dikarenakan banyaknya rendemen yang didapatkan, yaitu $20-35 \%$ bobot kering (Herbstreith dan Fox, 2006).

Penelitian ini bertujuan untuk mengkaji CMC dan ekstrak kulit jeruk sebagai pelapis benih dalam mempertahankan mutu fisiologis benih melon (Cucumis melo L.) selama penyimpanan.

\section{MATERI DAN METODE}

Penelitian telah dilaksanakan pada Desember 2016 - April 2017 di Laboratorium Fisiologi dan Pemuliaan Tanaman, Fakultas Peternakan dan
Pertanian, Universitas Diponegoro Semarang.

\section{Materi}

Bahan yang digunakan adalah benih melon varietas Ladika, ekstrak kulit jeruk Baby Pacitan $(0,5 \%, 1 \%, 1,5 \%, 2 \%)$, CMC 1,5\%, gliserol, $\mathrm{C}_{6} \mathrm{H}_{8} \mathrm{O}_{7}, \mathrm{CaCl}_{2}$, aquades, $\mathrm{HCl} 0,2 \mathrm{~N}$ dan alkohol $96 \%$. Alat yang digunakan adalah blender, timbangan analitik, pipet, magnetic stirrer, kertas lakmus, gelas beaker, erlenmeyer, corong gelas, kertas saring, pengaduk, loyang, kertas label, gunting, nampan, tisu, plastik polypropilene, pinset, EC meter, alat pengecambah, oven, sprayer dan alat tulis.

\section{Metode}

Penelitian diawali dengan ekstraksi kulit jeruk Baby Pacitan sebanyak 255 g. Kulit jeruk dipotong kecil-kecil, kemudian dikeringkan menggunakan oven pada suhu $55^{\circ} \mathrm{C}$ selama 48 jam. Potongan kulit jeruk diblender. Tepung kulit jeruk sebanyak $30 \mathrm{~g}$ diletakkan ke dalam gelas beaker yang berjumlah 6 buah, kemudian ditambahkan $\mathrm{HCl}$ 0,2 $\mathrm{N}$ yang telah dilarutkan ke dalam $150 \mathrm{~mL}$ aquades tiap gelas beaker. Ekstraksi dengan dipanaskan pada suhu $80^{\circ} \mathrm{C}$ selama 2 jam disertai pengadukan. Filtrat hasil ekstraksi diambil dan ditambahkan alkohol 96\% (1:1). Pengendapan dilakukan selama 24 jam. Endapan yang terbentuk disaring dan dimurnikan menggunakan alkohol 96\%. Endapan pektin dikeringkan menggunakan oven $50^{\circ} \mathrm{C}$ selama 8 jam. Pektin diblender untuk mendapatkan tepung pektin sebanyak 6,35 $\mathrm{g}$ (Widiastuti, 2015).

Pelapisan benih dimulai dengan menyiapkan CMC 1,5\%, ekstrak kulit jeruk $0,5 \%, 1 \%, 1,5 \%$, $2 \%$. Masing-masing perlakuan dilarutkan dengan aquades, diletakkan di atas magnetic stirrer. Setelah tercampur, ditambahkan gliserol $1 \mathrm{ml}$. Larutan dipanaskan pada suhu $40^{\circ} \mathrm{C}$ dan diaduk selama 15 menit. Larutan didinginkan dengan suhu ruang dan diukur $\mathrm{pH}$ sampai 6 dengan menambahkan $\mathrm{C}_{6} \mathrm{H}_{8} \mathrm{O}_{7} \quad 0,5 \mathrm{~g}$ dan $\mathrm{CaCl}_{2} \quad 0,5 \mathrm{~g}$ (Alexandra dan Nurlina, 2014). Pelapisan benih dilakukan dengan memasukkan benih ke dalam formula pelapis sesuai dengan perlakuan selama 5 - 10 menit. Benih melon dikering-anginkan, kemudian disimpan dalam plastik polypropylene 
pada suhu kamar selama 12 minggu masa penyimpanan (Setiyowati et al., 2007). Pengecambahan benih menggunakan Uji Kertas Digulung di atas plastik (UKDdp), kemudian diletakkan di dalam alat pengecambah. Pengamatan dilakukan pada hari ke-4 dan hari ke8 (Sutopo, 1998; ISTA, 2004; Cardoso et al., 2015). Parameter yang diamati adalah kadar air benih, daya berkecambah, kecepatan tumbuh benih, indeks vigor dan berat kering kecambah normal.

\section{Rancangan Percobaan dan Analisis Data}

Rancangan yang digunakan adalah Rancangan Acak Lengkap (RAL) pola faktorial $4 \times 6$. Faktor pertama adalah periode simpan terdiri dari A0 (0 minggu), A1 (4 minggu), A2 (8 minggu), A3 (12 minggu). Faktor kedua adalah pelapisan benih terdiri dari B0 (tanpa pelapisan), B1 (CMC 1,5\%), B2 (ekstrak kulit jeruk 0,5\%), B3 (ektrak kulit jeruk 1\%), B4 (ekstrak kulit jeruk 1,5\%), B5 (ekstrak kulit jeruk 2\%). Percobaan terdiri dari 24 perlakuan dan setiap perlakuan diulang sebanyak tiga ulangan, jadi total percobaan adalah 72 unit percobaan. Analisis ragam terhadap hasil pengamatan dilakukan dengan uji $\mathrm{F}$ dan uji lanjut Duncan Multiple Range Test (DMRT) pada taraf $5 \%$.

\section{HASIL DAN PEMBAHASAN}

\section{Kadar Air Benih}

Kadar air benih merupakan kandungan air yang terdapat dalam benih (McComarck, 2004). Data hasil pengamatan kadar air benih dari masing-masing perlakuan disajikan pada Tabel 1 . Hasil analisis ragam pada Tabel 1 menunjukkan bahwa periode simpan, pelapisan benih dan interaksinya berpengaruh nyata terhadap kadar air benih melon.

Kadar air benih melon pada perlakuan kontrol minggu ke-0 berbeda nyata dengan minggu ke-4, minggu ke-8 dan minggu ke-12. Kadar air benih pada perlakuan kontrol meningkat disebabkan oleh suhu ruang penyimpanan benih. Sutopo (2004) menyatakan bahwa suhu tinggi pada penyimpanan dapat menyebabkan kerusakan pada benih, karena dapat memperbesar dan menyebabkan zat cair dalam benih. Kadar air benih melon pada perlakuan CMC 1,5\% minggu ke- 0 berbeda nyata dengan minggu ke- 4 , minggu ke-8 dan minggu ke-12. Tingginya kadar air benih melon dengan perlakuan CMC 1,5\% disebabkan oleh bahan pelapis belum menguap secara maksimal pada proses pengeringan. Menurut Manggung et al. (2014) bahwa kadar air benih

Tabel 1. Pengaruh pelapisan benih pada periode simpan berbeda terhadap kadar air benih melon

\begin{tabular}{|c|c|c|c|c|c|c|c|}
\hline \multirow{2}{*}{$\begin{array}{l}\text { Periode } \\
\text { Simpan }\end{array}$} & \multicolumn{6}{|c|}{ Konsentrasi Pelapisan Benih } & \multirow[t]{2}{*}{ Rata-rata } \\
\hline & Kontrol & $\begin{array}{l}\text { CMC } \\
1,5 \%\end{array}$ & $\begin{array}{c}\text { EKJ } 0,5 \\
\%\end{array}$ & $\begin{array}{c}\text { EKJ } 1,0 \\
\%\end{array}$ & $\begin{array}{c}\text { EKJ } 1,5 \\
\%\end{array}$ & $\begin{array}{c}\text { EKJ } 2,0 \\
\%\end{array}$ & \\
\hline \multicolumn{8}{|l|}{ Minggu ke- } \\
\hline 0 & $8,32^{\mathrm{i}}$ & $10,62^{\mathrm{fg}}$ & $9,24^{\mathrm{h}}$ & $9,40^{\mathrm{h}}$ & $10,48^{\mathrm{g}}$ & $10,44^{\mathrm{g}}$ & $9,75^{\mathrm{d}}$ \\
\hline 4 & $10,40^{\mathrm{g}}$ & $11,53^{\mathrm{d}}$ & $10,20^{\mathrm{g}}$ & $10,18^{\mathrm{g}}$ & $10,70^{\mathrm{fg}}$ & $10,74^{\mathrm{e}-\mathrm{g}}$ & $10,63^{\mathrm{c}}$ \\
\hline 8 & $11,20^{\mathrm{d}-\mathrm{f}}$ & $11,88^{\mathrm{cd}}$ & $11,25^{\mathrm{d}-\mathrm{f}}$ & $11,26^{\mathrm{d}-\mathrm{f}}$ & $11,47^{\mathrm{d}}$ & $11,41^{\mathrm{de}}$ & $11,41^{\mathrm{b}}$ \\
\hline 12 & $12,60^{\mathrm{ab}}$ & $12,96^{\mathrm{a}}$ & $12,53^{\mathrm{abc}}$ & $12,41^{\mathrm{abc}}$ & $12,20^{\mathrm{bc}}$ & $12,77^{\mathrm{ab}}$ & $12,58^{\mathrm{a}}$ \\
\hline Rata-rata & $10,63^{c}$ & $11,75^{\mathrm{a}}$ & $10,80^{\mathrm{c}}$ & $10,81^{\mathrm{c}}$ & $11,21^{\mathrm{b}}$ & $11,34^{\mathrm{b}}$ & \\
\hline eterangan: $\mathrm{A}$ & natriks is & & & & & & $\begin{array}{l}\text { berbeda nyata } \\
\text { baris rata-rata } \\
\text { If yang berbeda }\end{array}$ \\
\hline
\end{tabular}


pada perlakuan pelapisan lebih tinggi dibandingkan kontrol disebabkan setelah proses pelapisan benih, pengeringan yang dilakukan kurang sempurna sehingga kandungan air benih maupun bahan pelapis belum menguap secara maksimal. Peningkatan kadar air benih melon dengan CMC 1,5\% dapat disebabkan oleh poripori pada bahan pelapis. Menurut Santoso et al. (2011) bahwa pori-pori yang terdapat pada matrik bahan pelapis sangat berpengaruh terhadap laju transmisi uap air, semakin banyak pori-pori semakin mudah uap air menembus bahan pelapis tersebut.

Kadar air benih melon pada perlakuan perlakuan EKJ 0,5 \% dan EKJ 1,0 \% minggu ke-0 berbeda nyata dengan minggu ke- 4 , minggu ke- 8 dan minggu ke-12. Pelapisan dengan EKJ 0,5\% dan EKJ 1,0 \% tidak dapat mempertahankan kadar air benih selama penyimpanan disebabkan oleh konsentrasi bahan pelapis yang rendah. Kadar air benih melon pada perlakuan EKJ 1,5 \% dan EKJ $2,0 \%$ minggu ke- 0 tidak berbeda nyata dengan minggu ke-4, tetapi berbeda nyata dengan minggu ke-8 dan minggu ke-12. Pelapisan dengan EKJ 1,5 $\%$ dan EKJ 2,0 \% mampu mempertahankan kadar air benih hingga minggu ke-4 disebabkan oleh bahan pelapis ekstrak kulit jeruk berupa pektin bersifat higroskopis. Hal ini sesuai dengan Permatasari (1999) bahwa sifat pektin higroskopis dapat mempengaruhi kadar air. Dhaneswari et al.
(2015) menambahkan bahwa pektin dapat mengikat air, sehingga kandungan air benih dapat dikendalikan oleh bahan pelapis tersebut.

Kadar air benih melon mengalami peningkatan selama penyimpanan (Tabel 1). Peningkatan kadar air benih dapat disebabkan oleh proses metabolisme benih. Hal ini sesuai dengan pendapat Halimursyadah (2012) bahwa metabolisme benih menyebabkan benih melon mudah menyerap dan mengeluarkan uap air dari udara hingga kandungan airnya seimbang dengan udara disekitarnya.

\section{Daya Berkecambah}

Daya berkecambah merupakan kemampuan tumbuh benih pada suhu optimum. Data hasil pengamatan daya berkecambah dari masingmasing perlakuan disajikan pada Tabel 2. Hasil analisis ragam pada Tabel 2 menunjukkan bahwa periode simpan, pelapisan benih dan interaksinya berpengaruh nyata terhadap daya berkecambah benih melon.

Daya berkecambah pada perlakuan kontrol minggu ke-0 tidak berbeda nyata dengan minggu ke-4 dan minggu ke- 8 , tetapi berbeda nyata dengan minggu ke-12. Perlakuan kontrol dapat mempertahankan daya berkecambah benih melon hingga minggu ke-4. Menurut Halimursyadah (2012) bahwa penurunan daya berkecambah

Tabel 2. Pengaruh Pelapisan Benih pada Periode Simpan Berbeda terhadap Daya Berkecambah Benih Melon

\begin{tabular}{|c|c|c|c|c|c|c|c|}
\hline \multirow[b]{2}{*}{$\begin{array}{l}\text { Periode } \\
\text { Simpan }\end{array}$} & \multicolumn{6}{|c|}{ Pelapisan Benih (Konsentrasi) } & \multirow{2}{*}{ Rata-rata } \\
\hline & Kontrol & $\begin{array}{l}\text { CMC } \\
1.5 \%\end{array}$ & $\begin{array}{c}\text { EKJ } \\
0.5 \%\end{array}$ & $\begin{array}{c}\text { EKJ } \\
1.0 \%\end{array}$ & $\begin{array}{c}\text { EKJ } \\
1.5 \%\end{array}$ & $\begin{array}{c}\text { EKJ } \\
2.0 \%\end{array}$ & \\
\hline Minggu ke- & & then & 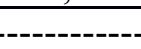 & ------\%--- & 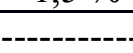 & $2,0>10$ & --- \\
\hline 0 & $82,67^{\mathrm{e}-\mathrm{i}}$ & $83,33^{\mathrm{d}-\mathrm{j}}$ & $78,67^{\text {hij }}$ & $76,67^{\mathrm{ij}}$ & $88,67^{\mathrm{b}-\mathrm{g}}$ & $74,00^{\mathrm{j}}$ & $80,67^{\mathrm{c}}$ \\
\hline 4 & $86,00^{c-j}$ & $93,33^{\mathrm{abc}}$ & $92,67^{\mathrm{abc}}$ & $96,67^{\mathrm{ab}}$ & $97,33^{\mathrm{a}}$ & $92,00^{\mathrm{a}-\mathrm{d}}$ & $93,00^{\mathrm{a}}$ \\
\hline 8 & $89,33^{\mathrm{a}-\mathrm{f}}$ & $88,67^{\mathrm{b}-\mathrm{g}}$ & $91,33^{\mathrm{a}-\mathrm{e}}$ & $86,67^{\mathrm{c}-\mathrm{h}}$ & $89,33^{\mathrm{a}-\mathrm{f}}$ & $90,00^{\mathrm{a}-\mathrm{f}}$ & $89,22^{b}$ \\
\hline 12 & $79,33^{\mathrm{g}-\mathrm{j}}$ & $80,67^{\mathrm{f}-\mathrm{j}}$ & $86,67^{\mathrm{ch}}$ & $90,00^{\mathrm{a}-\mathrm{f}}$ & $88,00^{\mathrm{c}-\mathrm{h}}$ & $76,00^{\mathrm{j}}$ & $83,44^{\mathrm{c}}$ \\
\hline
\end{tabular}

Keterangan: Angka yang diikuti huruf yang berbeda pada kolom rata-rata menunjukkan berbeda nyata berdasarkan uji DMRT $5 \%$; Angka yang diikuti huruf yang berbeda pada baris rata-rata menunjukkan berbeda nyata berdasarkan uji DMRT $5 \%$; Angka yang diikuti huruf yang berbeda pada matriks interaksi menunjukkan berbeda nyata berdasarkan uji DMRT $5 \%$ 
melon disebabkan oleh peningkatan asam lemak bebas, sehingga cadangan makanan berkurang. Daya berkecambah pada perlakuan CMC 1,5\% minggu ke-0 tidak berbeda nyata dengan minggu ke-4, minggu ke-8 dan minggu ke-12. Pelapisan dengan CMC 1,5\% dapat mempertahankan daya berkecambah melon hingga minggu ke-12 disebabkan oleh bahan dasar CMC yaitu karbohidrat. Menurut JECFA (2000) bahwa CMC merupakan karbohidrat stabil yang dapat digunakan sebagai zat pembawa yang baik sehingga mampu melapisi benih secara kompak dan merata.

Daya berkecambah pada perlakuan EKJ 0,5 \%, EKJ 1,0 \% dan EKJ 1,5 \% minggu ke-0 tidak berbeda nyata dengan minggu ke- 4 , minggu ke- 8 dan minggu ke-12. Pelapisan dengan EKJ 0,5\%, EKJ 1,0 \% dan EKJ 1,5\% dapat mempertahankan daya berkecambah melon hingga minggu ke-12. Nilai daya berkecambah tertinggi adalah pada minggu ke-4 dengan pelapisan EKJ 1,5 \% yaitu 97,33 \%. Menurut Lesilolo et al. (2013) bahwa benih yang memiliki daya berkecambah tinggi menunjukkan bahwa benih tersebut memiliki cadangan makanan yang cukup di dalam endosperma yang digunakan sebagai sumber energi oleh benih ketika perkecambahan berlangsung. Daya berkecambah pada perlakuan dengan EKJ 2,0 \% minggu ke-0 tidak berbeda nyata dengan minggu ke-12, tetapi berbeda nyata dengan minggu ke-4 dan minggu ke- 8 . Pelapisan dengan EKJ 2,0 \% dapat mempertahankan daya berkecambah melon hingga minggu ke-8 disebabkan oleh kadar air benih melon. Hal ini sesuai dengan pendapat Palupi et al. (2012) bahwa viabilitas benih selama penyimpanan dipengaruhi oleh kadar air benih, suhu dan kelembaban udara ruang penyimpanan.

Daya berkecambah awal penyimpanan menunjukkan nilai rendah, kemudian pada minggu ke-4 meningkat dan menurun kembali pada minggu ke-8 dan minggu ke-12 (Tabel 2). Menurut Kortse et al. (2013) bahwa benih melon mengalami after-ripening, yaitu periode simpan benih melon selama $7-14$ hari setelah panen. Daya berkecambah benih melon tertinggi adalah pelapisan EKJ 1,5 \% pada minggu ke-4 yaitu 97,33 \%. Menurut Alexandra dan Nurlina (2014) menambahkan bahwa penambahan ekstrak kulit jeruk berupa pektin pada tomat dapat mempengaruhi proses metabolisme selama penyimpanan dan memperpanjang masa simpan. Kecepatan Tumbuh dan Indeks Vigor Benih Melon

\section{Kecepatan Tumbuh dan Indeks Vigor Benih Melon}

Kecepatan tumbuh benih merupakan jumlah tambahan kecambah normal tiap hari (Sadjad et al., 1999) yang dapat mengindikasikan vigor kekuatan tumbuh benih tinggi (Muchtar et al., 2014). Data hasil pengamatan kecepatan tumbuh dan indeks vigor dari masing-masing perlakuan disajikan pada Tabel 3.

Hasil analisis ragam pada Tabel 3 menunjukkan bahwa periode simpan dan pelapisan benih berpengaruh nyata terhadap kecepatan tumbuh benih dan indeks vigor serta tidak adanya interaksi antara periode simpan dan pelapisan benih melon.

Hasil uji Duncan pada kecepatan tumbuh benih menunjukkan bahwa minggu ke-0 berbeda nyata dengan minggu ke-4 dan minggu ke-8, tetapi tidak berbeda nyata dengan minggu ke-12. Kecepatan tumbuh benih mengalami peningkatan dari $25,46 \% \mathrm{KN} /$ etmal pada minggu ke- 0 menjadi $28,04 \% \mathrm{KN} /$ etmal pada minggu ke-4, menurun pada minggu ke-12 sebesar 25,16\%KN/etmal. Menurut Novita dan Suwarno (2014) bahwa kecepatan tumbuh benih melon $\geq 26,94$ $\% \mathrm{KN} /$ etmal pada kondisi optimum merupakan kecepatan tumbuh benih baik. Kecepatan tumbuh benih pada perlakuan kontrol tidak berbeda nyata dengan CMC 1,5 \%, EKJ 0,5 \%, EKJ 1,0 \%, dan EKJ 2,0 \%, tetapi berbeda nyata dengan EKJ 1,5 $\%$. Kecepatan tumbuh benih pada kontrol berbeda nyata dengan EKJ 1,5 \%. Penggunaan EKJ 1,5 \% menghasilkan nilai kecepatan tumbuh benih sebesar 27,90\% KN/etmal. Menurut Winarti et al. (2012) bahwa penggunaan bahan polisakarida dalam bahan pelapis dapat mencegah kehilangan uap air, menghalangi oksigen dan tekanan fisik selama penyimpanan sehingga membran sel tidak mengalami kebocoran sel.

Hasil uji Duncan pada indeks vigor menunjukkan bahwa minggu ke-0 tidak berbeda nyata dengan minggu ke-4 dan minggu ke-8, tetapi berbeda nyata dengan minggu ke-12. Indeks vigor mengalami penurunan dari $83,33 \%$ pada 
Tabel 3. Pengaruh Pelapisan Benih pada Periode Simpan Berbeda terhadap Kecepatan Tumbuh (\%KN/etmal) dan Indeks Vigor (\%) Benih Melon

\begin{tabular}{|c|c|c|c|c|c|c|c|}
\hline \multirow[b]{2}{*}{ Periode Simpan } & \multicolumn{6}{|c|}{ Pelapisan Benih (Konsentrasi) } & \multirow[b]{2}{*}{ Rata-rata } \\
\hline & Kontrol & $\begin{array}{l}\text { CMC } \\
1,5 \% \\
\end{array}$ & $\begin{array}{c}\text { EKJ } \\
0,5 \% \\
\end{array}$ & $\begin{array}{c}\text { EKJ } \\
1,0 \% \\
\end{array}$ & $\begin{array}{c}\text { EKJ } \\
1,5 \% \\
\end{array}$ & $\begin{array}{c}\text { EKJ } \\
2,0 \% \\
\end{array}$ & \\
\hline Minggu ke- & \multicolumn{7}{|c|}{------------ Kecepatan Tumbuh Benih (\%KN/etmal) -------------- } \\
\hline 0 & 25,72 & 25,35 & 24,83 & 25,00 & 27,89 & 23,93 & $25,46^{\mathrm{b}}$ \\
\hline 4 & 27,72 & 26,03 & 28,30 & 29,26 & 29,57 & 27,33 & $28,04^{\mathrm{a}}$ \\
\hline 8 & 27,90 & 26,40 & 28,14 & 26,66 & 27,94 & 27,23 & $27,38^{\mathrm{a}}$ \\
\hline 12 & 23,59 & 24,46 & 25,70 & 27,11 & 26,20 & 23,91 & $25,16^{\mathrm{b}}$ \\
\hline Rata-rata & $26,23^{\mathrm{bc}}$ & $25,56^{\mathrm{c}}$ & $26,74^{\mathrm{abc}}$ & $27,01^{\mathrm{ab}}$ & $27,90^{\mathrm{a}}$ & $25,60^{\mathrm{c}}$ & \\
\hline Minggu ke- & \multicolumn{7}{|c|}{ 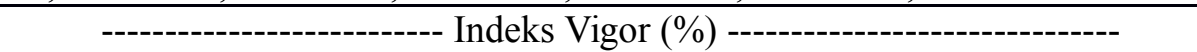 } \\
\hline 0 & 82,67 & 75,33 & 78,67 & 76,67 & 88,67 & 72,67 & $79,11^{\mathrm{a}}$ \\
\hline 4 & 86,00 & 70,00 & 86,00 & 84,00 & 88,67 & 84,00 & $83,11^{\mathrm{a}}$ \\
\hline 8 & 86,00 & 82,00 & 88,67 & 80,00 & 86,00 & 77,33 & $83,33^{a}$ \\
\hline 12 & 61,33 & 68,67 & 72,67 & 76,67 & 74,67 & 72,00 & $71,00^{\mathrm{b}}$ \\
\hline Rata-rata & $79,00^{\mathrm{abc}}$ & $74,00^{\mathrm{c}}$ & $81,50^{\mathrm{ab}}$ & $79,33^{\mathrm{abc}}$ & $84,50^{\mathrm{a}}$ & $76,50^{\mathrm{bc}}$ & \\
\hline
\end{tabular}

Keterangan: Angka yang diikuti oleh huruf yang berbeda pada kolom rata-rata pada setiap tolok ukur menunjukkan berbeda nyata berdasarkan uji DMRT $5 \%$; Angka yang diikuti oleh huruf yang berbeda pada baris rata-rata pada setiap tolok ukur menunjukkan berbeda nyata berdasarkan uji DMRT $5 \%$

minggu ke-8 menjadi 71,00\% pada minggu ke- 12 . Menurut Cardoso et al. (2015) bahwa rata-rata $93,2 \%$ menunjukkan vigor benih melon tinggi. Indeks vigor benih melon pada perlakuan kontrol tidak berbeda nyata dengan CMC $1,5 \%$, EKJ 0,5 $\%$, EKJ 1,0 \%, dan EKJ 2,0 \%. Indeks vigor benih dengan pelapisan EKJ 1,5 \% tidak berbeda nyata dengan kontrol. Menuru Umar (2012) menambahkan bahwa kebocoran membran sel akibat kemunduran benih menyebabkan penurunan vigor dipercepat. Pada awal penyimpanan dari semua perlakuan relatif rendah, kemudian meningkat lalu turun kembali yang disebabkan oleh proses after-ripening pada benih melon selama 7 - 14 hari setelah panen (Kortse et al., 2013) .

\section{Berat Kering Kecambah Normal}

Berat kering kecambah normal merupakan kemampuan benih dalam mengunakan cadangan makanannya untuk tumbuh menjadi kecambah normal (Muchtar et al., 2014). Data hasil pengamatan berat kering kecambah normal dari masing-masing perlakuan disajikan pada Tabel 4 .
Hasil analisis ragam pada Tabel 4 menunjukkan bahwa periode simpan, pelapisan benih dan interaksinya berpengaruh nyata terhadap berat kering kecambah normal.

Berat kering kecambah normal pada perlakuan kontrol minggu ke-0 berbeda nyata dengan minggu ke-4, minggu ke-8 dan minggu ke12. Perlakuan kontrol tidak dapat mempertahankan berat kering kecambah normal selama penyimpanan disebabkan oleh sedikitnya cadangan makanan pada benih. Menurut Tirawati (2012) bahwa kemampuan berkecambah benih berkaitan dengan cadangan makanan yang dikandungnya sehingga produksi berat kering dari pertumbuhan kecambah akan menggambarkan kondisi fisiologis benih dan aktivitas metabolisme yang terjadi di dalam benih. Berat kering kecambah normal pada perlakuan CMC 1,5\% minggu ke- 0 tidak berbeda nyata dengan minggu ke- 8 , tetapi berbeda nyata dengan minggu ke-4 dan minggu ke-12. Pelapisan dengan CMC 1,5\% dapat mempertahankan berat kering kecambah normal hingga minggu ke-8 disebabkan oleh bahan pelapis yang digunakan dalam pelapisan benih. Menurut JECFA (2000) bahwa CMC 
Tabel 4. Pengaruh Pelapisan Benih pada Periode Simpan Berbeda terhadap Berat Kering Kecambah Normal Melon

\begin{tabular}{|c|c|c|c|c|c|c|c|}
\hline \multirow[b]{2}{*}{ Periode Simpan } & \multicolumn{6}{|c|}{ Pelapisan Benih (Konsentrasi) } & \multirow[b]{2}{*}{ Rata-rata } \\
\hline & Kontrol & $\begin{array}{l}\text { CMC } \\
1,5 \%\end{array}$ & $\begin{array}{c}\text { EKJ } \\
0,5 \%\end{array}$ & $\begin{array}{c}\text { EKJ } \\
1,0 \%\end{array}$ & $\begin{array}{c}\text { EKJ } \\
1,5 \%\end{array}$ & $\begin{array}{c}\text { EKJ } \\
2,0 \%\end{array}$ & \\
\hline Minggu ke- & & & & $-----\mathrm{g}-$ & --------- & ---------- & ---- \\
\hline 0 & $0,489^{\mathrm{bc}}$ & $0,562^{\mathrm{ab}}$ & $0,467^{\mathrm{cd}}$ & $0,519^{\mathrm{abc}}$ & $0,460^{\text {cde }}$ & $0,486^{\mathrm{bc}}$ & $0,497^{\mathrm{a}}$ \\
\hline 4 & $0,197^{\mathrm{hi}}$ & $0,363^{\mathrm{f}}$ & $0,298^{\text {fgh }}$ & $0,348^{\mathrm{f}}$ & $0,302^{\mathrm{fg}}$ & $0,340^{\mathrm{f}}$ & $0,308^{c}$ \\
\hline 8 & $0,217^{\text {ghi }}$ & $0,599^{\mathrm{a}}$ & $0,377^{\text {def }}$ & $0,350^{\mathrm{f}}$ & $0,370^{\text {ef }}$ & $0,355^{\mathrm{f}}$ & $0,378^{\mathrm{b}}$ \\
\hline 12 & $0,022^{\mathrm{i}}$ & $0,346^{\mathrm{f}}$ & $0,206^{\text {ghi }}$ & $0,163^{\mathrm{i}}$ & $0,209^{\text {ghi }}$ & $0,207^{\text {ghi }}$ & $0,192^{\mathrm{d}}$ \\
\hline Rata-rata & $0,231^{\mathrm{c}}$ & $0,468^{\mathrm{a}}$ & $0,337^{\mathrm{b}}$ & $0,345^{\mathrm{b}}$ & $0,335^{\mathrm{b}}$ & $0,347^{\mathrm{b}}$ & \\
\hline $\begin{array}{ll}\text { terangan: Angka } \\
\text { berdasa }\end{array}$ & ng diikut & & berbeda & da kolo & & nunjukkar & erbeda nyat \\
\hline
\end{tabular}

merupakan karbohidrat stabil yang dapat digunakan sebagai zat pembawa yang baik, sehingga benih kompak dan merata. Manggung et al. (2014) menambahkan bahwa aktivitas enzim terutama enzim respirasi dapat ditekan dan menurunnya cadangan makanan dapat diperlambat dengan pelapisan benih.

Berat kering kecambah normal pada perlakuan EKJ 0,5 \% dan EKJ 1,5 \% minggu ke-0 berbeda nyata dengan minggu ke-4 dan minggu ke- 8 , tetapi tidak berbeda nyata dengan minggu ke-12. Pelapisan dengan EKJ 0,5 \% dan EKJ 1,5 $\%$ dapat mempertahankan berat kering kecambah normal hingga minggu ke-8. Tingginya berat kering kecambah normal disebabkan banyaknya cadangan makanan dalam benih. Menurut Alexandra dan Nurlina (2014) bahwa penambahan pektin akan mempengaruhi proses metabolisme, memperpanjang masa simpan, meningkatkan nilai gizi dan memperbaiki penampilan. Berat kering kecambah normal pada perlakuan EKJ 1,0 \% dan EKJ 2,0 \% minggu ke-0 berbeda nyata dengan minggu ke-4, minggu ke-8 dan minggu ke-12. Pelapisan dengan EKJ 1,0 \% dan EKJ 2,0 \% tidak dapat mempertahankan berat kering kecambah normal selama penyimpanan disebabkan oleh indeks vigor yang rendah. Menurut Copeland (1980) bahwa benih yang memiliki vigor benih yang rendah menyebabkan kemunduran benih, kecepatan berkecambah menurun, kepekaan serangan hama, meningkatnya jumlah kecambah abnormal dan rendahnya produksi tanaman.

Berat kering kecambah normal melon mengalami fluktuatif (Ilustrasi 8). Pelapisan benih menunjukkan nilai berat kering kecambah normal tinggi dibandingkan dengan kontrol. Menurut Manggung et al. (2014) bahwa aktivitas enzim respirasi dapat ditekan dan menurunnya cadangan makanan dapat diperlambat dengan pelapisan benih.

\section{KESIMPULAN}

Perlakuan pelapisan mampu mempertahankan kadar air benih, daya hantar listrik, daya berkecambah, panjang plumula dan berat kering kecambah normal dibandingkan kontrol. Bahan pelapis ekstrak kulit jeruk 1,5\% dapat mempertahankan kadar air benih hingga minggu ke-4, daya berkecambah hingga minggu ke-12 serta berat kering kecambah normal hingga minggu ke-8.

\section{DAFTAR PUSTAKA}

Agustiansyah, A., B. Paul., T. Timotiwu dan D. Rosalia. 2016. Pengaruh pelapisan benih terhadap perkecambahan benih padi (Oryza sativa L.) pada kondisi media kertas keracunan alumunium. Agrovigor 9 (1): 2432. 
Alexandra, Y. dan N. Nurlina. 2014. Aplikasi edible coating dari pektin jeruk songhi Pontianak (Citrus nobilis var Microcarpa) pada penyimpanan buah tomat. Jurnal Kimia Khatulistiwa 3 (4) : 11-20.

Badan Pusat Statistik. 2016. Statistik Tanaman Sayuran dan Buah-buahan Semusim Indonesia 2016. Badan Pusat Statistik, Jakarta.

Cardoso, A. I. I., A.Z. Kronka., N.B.L. Lanna., P.N.L. Silva., L.F. Colombari., P.L.Santos dan C.G. Pierozzi. 2015. Germination, vigor and fungi incidence in melon seeds treated with Thiabendazole. African Journal of Agricultural Research 10 (35): 3472-3476.

Dhaneswari, P., C.G. Sula., Z. Ulima dan P. Andriana. 2015. Pemanfaatan pektin yang diisolasi dari kulit dan buah salak (Slacca Edulis Reinw) dalam uji in vivo penurunan kadar kolesterol dan glukosa darah pada tikus jantan galur wistar. Khazanah 7 (2) : 39-51.

Georgiev, Y., M. Ongnyanov., I. Yanakieva., V. Kussovski dan M. Kratchanova. 2012. Isolation, characterization and modification of citrus pectins. J. BioSci. Biotech 1 (3): 223-233.

Halimursyadah, H. 2012. Pengaruh kondisi simpan terhadap viabilitas dan vigor benih Avicennia marina (Forsk.) Vierh, pada beberapa periode simpan. Jurnal Agrotropika 17 (2) : 43-51.

ISTA (International Seed Testing Association). 2004. Seed Science and Technology, International Rules for Seed Testing. International Seed Testing Association, Zurich.

JECFA (Joint FAO/WHO Expert Commiittee on Food Additives). 2000. Sodium Carboxylmethyl Cellulose. Published in FNP 52 Add 8.

Kortse, K., P. Aloho, O. Oladiran dan A. Johnson.
2013. Effect of season, time of fruit harvesting and after-ripening on the quality of egusi melon [Citrulus kanatus (Thunb.) Matsum and Nakai] seed. International Journal of Scientific and Research Publications 3 (2): 1-10.

Kuswanto, H. 2003. Teknologi Pemrosesan, Pengemasan dan Penyimpanan Benih. Kanisius, Yogyakarta.

Lesilolo, M. K., J. Riry dan E.A. Matatula. 2013. Pengujian viabilitas dan vigor benih beberapa jenis tanaman yang beredar di pasaran kota Ambon. Agrologia 2 (1): 1-9.

Manggung, R. E. R., S. Ilyas dan Y. Bakhtiar. 2014. Evaluasi daya simpan benih kedelai yang diberi perlakuan pelapisan benih dengan cendawan mikoriza arbuskula. J. Agron. Indonesia 42 (2): 103-109.

McCormack, J. 2004. Seed Processing and Storage: Principles and Practices. www.savinggourseeds.org.

Muchtar, S. D., E. Widajati dan G. Giyanto. 2014. Pelapisan benih menggunakan bakteri probiotik untuk mempertahankan viabilitas benih jagung manis (Zea mays saccharata Sturt.) selama penyimpanan. Bul. Agrohorti 1 (4) : 26-33.

Novita, N. dan F.C. Suwarno. 2014. Viabilitas benih melon (Cucumis melo L.) pada kondisi optimum dan sub-optimum setelah diberi perlakuan invigorasi. Bul. Agrohorti 2 (1): 59-65.

Palupi, T., S. Ilyas, M. Machmud dan E. Widajati. 2012. Coating benih dengan agen hayati untuk meningkatkan pertumbuhan dan hasil tanaman padi. J. Agron. Indon. 41 (3): 175180 .

Pitojo, S. 2005. Benih Tomat. Kanisius, Yogyakarta.

Sadjad, S., E. Murniati dan S. Ilyas. 1999. Parameter Pengujian Vigor Benih. Grassindo, 
Jakarta.

Sulihono, A., B. Tarirohan dan T.E. Agustina. 2012. Pengaruh waktu, temperature dan jenis pelarut terhadap ekstraksi pektin dari kulit jeruk bali (Citrus maxima). Jurnal Teknik Kimia 4 (18) : 1-8.

Sutopo, L. 2004. Teknologi Benih. Rajawali Press, Jakarta.

Umar, S. 2012. Pengaruh pemberian organik terhadap daya simpan benih kedelai
(Glycine max (L.) Merr.). Ber. Bio 11 (3).

Widiastuti, D. R. 2015. Ekstraksi pektin kulit jeruk Bali dengan metode microwave assisted extraction dan aplikasinya sebagai edible film. Skripsi. Universitas Negeri Semarang, Semarang.

Winarti, C., M. Miskiyah dan W. Widaningrum. 2012. Teknologi produksi dan aplikasi pengemas edible antimkiroba berbasis pati. Balai Besar Penelitian dan Pengembangan Pascapanen Pertanian 31 (3):85-93. 